\title{
Role of Renal Sympathetic Nerves in Lambs during the Transition from Fetal to Newborn Life
}

Francine G. Smith, Bruce A. Smith, Edward N. Guillery, and Jean E. Robillard

With the technical assistance of Sherry Flansburg and Oliva J. McWeeny

Department of Pediatrics and Cardiovascular Center, University of Iowa, Iowa City, Iowa 52242

\begin{abstract}
To determine the role of renal sympathetic nerves in influencing renal function during the transition from fetal to newborn life, studies were carried out in conscious, chronically instrumented fetal sheep with either bilateral renal denervation ( $n$ $=11$ ) or intact renal nerves $(n=12), 3-6 \mathrm{~d}$ after surgery. Endocrine, renal, and cardiovascular parameters were measured before and after delivery of lambs by cesarean section. Blood pressure and heart rate were similar in intact and denervated fetuses, and increased after delivery in both groups. There was also a transient diuresis and natriuresis, in the immediate postnatal period, the response being significantly greater in denervated than intact lambs $(P<0.05)$. By 24 h postnatally, fluid and electrolyte excretions were similar in both groups, and significantly less than fetal levels. In the absence of renal nerves, the normal rise in plasma renin activity at birth was attenuated. These data provide evidence that renal sympathetic nerves play an important role during the transition from fetal to newborn life, and support the premise that birth is associated with sympathetic activation. (J. Clin. Invest. 1991.88:1988-1994.) Key words: neonate $\bullet$ renal function • atrial natriuretic factor • plasma renin activity $\bullet$ birth
\end{abstract}

\section{Introduction}

In the adult animal, renal sympathetic nerves influence renin secretion, renal hemodynamics, and renal function (1), through activation of adrenergic receptors located on renal vessels and tubules. In the immature animal, stimulation of renal nerves (2) or of renal $\alpha_{1}$-adrenergic receptors (3), results in a vasoconstriction, though to a lesser extent than later in life. Similarly, in fetal and newborn sheep, neuronal release of norepinephrine causes renin release in vitro, from renal cortical slices (4). Recent evidence indicates that stimulation of renal nerves of fetal and newborn sheep increases fractional $\mathrm{Na}^{+}$ reabsorption (5). These data suggest that renal sympathetic nerves in the immature animal, as in the adult, may regulate renin release and influence renal hemodynamics and function.

A preliminary report of this manuscript was presented to the Society for Pediatric Research, 1991.

Address correspondence Francine G. Smith, Ph.D., Department of Obstetrics/Gynaecology and Medical Physiology, Reproductive Medicine Research Group, Heritage Medical Research Building, 3330 Hospital Drive NW, Calgary, Alberta T2N 4N1 Canada.

Received for publication 22 April 1991 and in revised form 22 July 1991.

J. Clin. Invest.

(c) The American Society for Clinical Investigation, Inc.

0021-9738/91/12/1988/07 \$2.00

Volume 88, December 1991, 1988-1994
It is well recognized that the transition from fetal to newborn life is associated with an increase in the activity of the renin-angiotensin system and a surge in plasma catecholamines, these hormonal changes being slightly attentuated in cesarean compared with vaginal delivery (6-12). In newborn lambs delivered by cesarean section, there is a marked increase in fractional $\mathrm{Na}^{+}$reabsorption by $24 \mathrm{~h}$ postnatally, from fetal levels of $93 \%$ of the filtered $\mathrm{Na}^{+}$load to $99 \%$ (13-15), similar to that seen later in life. This rapid rise in fractional $\mathrm{Na}^{+}$reabsorption soon after birth, along with elevated plasma norepinephrine (NE) ${ }^{1}$ levels and plasma renin activity (PRA) suggests that the transition from fetal to newborn life is associated with increased sympathetic activity.

To determine whether renal sympathetic innervation influences renal and endocrine function at birth, studies were carried out in conscious, chronically instrumented fetal sheep with either bilateral renal denervation or intact renal nerves. Endocrine, renal, and cardiovascular parameters were measured before birth and after delivery of the lamb by cesarean section. Our results show that renal nerves play a major role in regulating renin release and renal function during the transition from fetal to newborn life.

\section{Methods}

Pregnant ewes of mixed breeding were obtained from a local source and housed in individual pens with free access to alfalfa pellets and water. Gestational ages were based on the induced ovulation technique (16)

Studies were carried out 3-6 d after surgery in 23 conscious, chronically instrumented fetal sheep aged $140 \mathrm{~d}$, before and after delivery by cesarean section. At surgery, described in detail in the following section, either bilateral renal denervation $(n=11)$ or sham denervation ( $n$ $=12$ ) was performed.

Surgical procedures. Surgery was carried out with the ewe and fetus under general anesthesia ( $1 \%$ halothane, $33 \%$ oxygen, $66 \%$ nitrous oxide), after induction with pentothal ( $500 \mathrm{mg}$ sodium thiopentone, Abbott Laboratories, Irving, TX), as previously described (17). Briefly, a uterine incision was made near the fetal hindlimbs; catheters were inserted into right and left femoral arteries and veins, and into the fetal bladder. Skin incisions were sutured and an additional catheter was sutured to the fetal skin for later measurement of intraamniotic pressure.

In the 11 fetuses submitted to renal denervation, bilateral flank incisions were made and renal nerves were severed and stripped from along the aorta, renal arteries, veins, and ureters. This was followed by careful application of $10 \%$ phenol in absolute alcohol to the renal plexus and surrounding area, as previously described $(18,19)$. Shamoperated fetuses were submitted to the same surgical procedure except that the renal nerves were left intact, and no phenol was applied (18,

1. Abbreviations used in this paper: ANF, atrial natriuretic factor; EPI, epinephrine, GFR, glomerular filtration rate; NE, norepinephrine; PRA, plasma renin activity; RBFV, renal blood flow velocity. 
19). In both groups, a pulsed Doppler flow probe was placed around the left renal artery (2).

Fetal skin incisions were then closed and the fetus was returned to the uterus. Uterine, maternal muscle, and maternal skin were sutured in separate layers. All catheters were exteriorized subcutaneously and placed in a cloth pouch on the ewe's flank. Ampicillin sodium was infused directly into the amniotic cavity $(1 \mathrm{~g})$ and administered intramuscularly ( $1 \mathrm{~g}$ ) to the ewe at surgery, and at 48-h intervals thereafter. All animals were standing and eating within $1 \mathrm{~h}$ of completion of surgery.

Dexamethasone $(5 \mathrm{mg})$ was administered intramuscularly to the ewe $18 \mathrm{~h}$ before experiments to ensure prevention of respiratory distress after delivery of the lamb by cesarean section.

Physiological studies. Before the start of experiments, the ewe was transferred to the laboratory in a small cart that permitted it to stand in an upright position. The fetal bladder was then drained and a priming dose of $\left[{ }^{14} \mathrm{C}\right]$-inulin $(2 \mu \mathrm{Ci})$ in $0.5 \mathrm{~g} /$ liter of dextrose in water was infused intravenously, followed by a constant infusion at $0.063 \mu \mathrm{Ci} / \mathrm{min}$, at a rate of $0.11 \mathrm{ml} / \mathrm{min}$, for later determination of glomerular filtration rate (GFR). After this 60 -min equilibration period, fetal urine was continuously collected for $30 \mathrm{~min}$.

Ewes were then returned to the surgical suite, and a 20-gauge spinal needle was inserted between the lumbar/sacral intervertebral space after infiltration with local anesthetic ( $1 \%$ lidocaine hydrochloride). This was followed by infusion of $10 \mathrm{ml}$ of $0.5 \%$ bupivicaine hydrochloride until analgesia of the lower body was achieved. The lamb was delivered by cesarean section within the ensuing $15 \mathrm{~min}$, as previously described $(14,15,20)$. Experiments were resumed $1 \mathrm{~h}$ after delivery of all lambs. During this $1-\mathrm{h}$ recovery period, infusion of $\left[{ }^{14} \mathrm{C}\right]$-inulin was resumed. An additional solution containing $0.5 \mathrm{~g} /$ liter of dextrose, 34 $\mathrm{mEq} / \mathrm{liter}$ of sodium chloride and $30 \mathrm{mEq} / \mathrm{liter}$ of potassium chloride, was infused intravenously at $0.07 \mathrm{ml} / \mathrm{kg}$ per min, during the recovery period and for the duration of the study. Urinary flow rate was continuously collected over 30 -min intervals at $1,4,8$, and $24 \mathrm{~h}$ after delivery.

Urinary volumes were recorded and samples stored at $-70^{\circ} \mathrm{C}$ for later determination of electrolytes $\left(\mathrm{Na}^{+}, \mathrm{K}^{+}\right)$, osmolality, and $\left[{ }^{14} \mathrm{C}\right]-$ inulin concentration. At the midpoint of each urinary collection period, $2.5 \mathrm{ml}$ of arterial blood were removed for immediate determination of $\mathrm{pH}, \mathrm{PO}_{2}$ and $\mathrm{PCO}_{2}$, and later determination of hematocrit, plasma electrolytes $\left(\mathrm{Na}^{+}, \mathrm{K}^{+}\right)$, plasma osmolality, and $\left[{ }^{14} \mathrm{C}\right]$-inulin concentration. Additional arterial blood $(9 \mathrm{ml})$ was removed at the end of each urine collection for later determination of plasma atrial natriuretic factor (ANF), aldosterone, catecholamines (NE and epinephrine [EPI]), and PRA. In lambs, blood samples were replaced with equivalent volumes of cord blood obtained at delivery, to avoid any hemodynamic effects of sampling.

During each experiment, mean arterial blood pressure (BP, corrected for intraamniotic pressure before delivery), heart rate (HR), and renal blood flow velocity (RBFV) were monitored continuously using a model P23Db pressure transducer (Statham Instruments, Schiller Park, IL), cardiotachometer, and a Doppler flowmeter. The validity of the pulsed Doppler flowmeter for measurement of RBFV in fetal and newborn sheep has previously been described (2). BP, HR, and RBFV were continuously recorded on-line to an IBM-XT computer using the software package Labtech Notebook (version 2.8; Laboratory Technology Corp., Wilmington, MA).

In 10 denervated and eight intact animals, in addition to measurements at 1, 4, 8, and $24 \mathrm{~h}$ after delivery, urinary flow rate, and $\mathrm{Na}^{+}$ excretion were measured continuously for $24 \mathrm{~h}$ and sampled at $30-\mathrm{min}$ intervals.

After completion of the study, lambs were killed with a lethal dose of sodium pentobarbitone, and upon postmortem, placement of all catheters was verified. Right and left kidneys were removed onto ice for later determination of renal tissue NE content to confirm the adequacy of renal denervation.

Analytical procedures. Arterial blood for measurement of $\mathrm{pH}, \mathrm{PCO}_{2}$ and $\mathrm{PO}_{2}$ was collected anaerobically and measured immediately at $39.5^{\circ} \mathrm{C}$ for fetuses, or at body temperature for lambs measured before sampling $\left(37.5-39.0^{\circ} \mathrm{C}\right)$, using an IL-1 $303 \mathrm{pH} / \mathrm{blood}$ gas analyzer (Laboratory Instruments). Hematocrit was determined in duplicate using a micrometer caliper. Plasma and urinary $\mathrm{Na}^{+}$and $\mathrm{K}^{+}$concentrations were determined by flame photometry (No. 430; Corning GlassWorks, Corning, NY). Plasma and urinary osmolalities were measured using a micro-osmometer (3MO; Advanced Instruments, Inc., Needham Heights, MA). Concentrations of $\left[{ }^{14} \mathrm{C}\right]$-inulin in plasma and urine were measured by liquid scintillation (LS-330; Beckman Instruments, Inc., Fullerton, CA).

Radioimmunoassays, previously established in our laboratories were used to measure plasma aldosterone (21), ANF (22), plasma and tissue catecholamines (23), and PRA (24).

Computations and data analyses. Changes in RBFV $(\% \Delta)$ were calculated as previously described (2), as percent of fetal levels. GFR was calculated as the clearance of $\left[{ }^{14} \mathrm{C}\right]$-inulin. Fractional excretion of electrolytes $\left(F E_{\mathrm{x}}\right)$ was determined as the ratio of electrolyte clearance $\left(C_{\mathrm{x}}\right)$ to the clearance of $\left[{ }^{14} \mathrm{C}\right]$-inulin $\left(C_{\mathrm{In}}\right): F E_{\mathrm{x}}(\%)=\left(C_{\mathrm{x}} / C_{\mathrm{ln}}\right) \times 100$. Free water clearance $\left(C_{\mathrm{H}_{2} \mathrm{O}}\right)$ was calculated as the difference between urinary flow rate $(V)$ and osmolar clearance $\left(C_{\mathrm{Oss}_{\mathrm{m}}}\right) . C_{\mathrm{H}_{2} \mathrm{O}}=V-C_{\mathrm{Osm}}$.

Data are expressed as mean \pm SEM. Changes within denervated or intact animals were determined using two-way ANOVA for repeated measures (25). Where the $F$ value was found to be significant, newborn data were compared with fetal data using Dunnett's multiple comparison tests (25). Denervated and intact animals were compared using Student's nonpaired $t$ tests. For all statistical tests, significance was accepted at the $95 \%$ confidence interval.

\section{Results}

Blood gas status and plasma electrolytes measured in intact and denervated lambs before and after delivery by cesarean section are shown in Table I. Arterial $\mathrm{Po}_{2}$ increased in intact $(F$ $=95.9 ; P<0.0001)$ and denervated lambs $(F=28.7 ; P$ $<0.0001$ ) after birth, the levels being higher in intact lambs at 4 and $8 \mathrm{~h}$. There was a transient acidosis in the first hour of postnatal life in both groups (Table I). Plasma $\mathrm{Na}^{+}$and $\mathrm{K}^{+}$ concentrations, and plasma osmolality remained constant after cesarean delivery in intact and denervated lambs. Hematocrit was greater in denervated than intact lambs $(P<0.05)$ before and after delivery. Hematocrit decreased after cesarean delivery in intact lambs $(F=3.88 ; P<0.001)$ returning to fetal levels by $8 \mathrm{~h}$. In denervated lambs, hematocrit showed no decrease after delivery $(F=0.61 ; P>0.05)$.

Fig. 1 illustrates the effects of cesarean delivery on BP, HR, and RBFV $(\% \Delta)$ measured in intact and denervated lambs. BP and HR were similar in intact and denervated fetuses $(P$ $>0.05)$. BP increased after cesarean delivery in both groups $(P$ $<0.0001$ ). There was a transient increase in HR $1 \mathrm{~h}$ after delivery; by $24 \mathrm{~h}, \mathrm{HR}$ was less than fetal values (Fig. 1). In lambs with intact renal nerves, $\mathrm{RBFV}$ remained constant after delivery $(F=2.22 ; P>0.05)$; in denervated lambs, there was a transient decrease in RBFV at $1 \mathrm{~h}(F=4.71 ; P<0.001)$. Changes in RBFV at $1 \mathrm{~h}$ were significantly different when intact and denervated lambs were compared $(t=2.79 ; P$ $<0.005$ ).

Renal function. GFR, urinary flow rate, electrolyte excretion rates $\left(U_{\mathrm{Na}} V, U_{\mathrm{K}} V\right)$ and fractional excretion of electrolytes $\left(F E_{\mathrm{Na}}, F E_{\mathrm{K}}\right)$ were similar in intact and denervated fetuses (Table II, Fig. 2). Birth had no effect on $U_{\mathrm{K}} V$ or $F E_{\mathrm{K}}$ in intact or denervated lambs (Table II). There was, however, a transient diuresis and natriuresis $1 \mathrm{~h}$ after delivery (Table II, Fig. 2), the responses being significantly greater in denervated than in intact animals $(P<0.05)$. By $24 \mathrm{~h}$ postnatally, $F E_{\mathrm{Na}}$ was significantly less than fetal levels in intact and in denervated lambs. 


\begin{tabular}{|c|c|c|c|c|c|c|}
\hline \multirow[b]{2}{*}{ Time } & & \multirow[b]{2}{*}{ Fetus } & \multicolumn{4}{|c|}{ Newborn } \\
\hline & & & $1 \mathrm{~h}$ & $4 \mathrm{~h}$ & $8 \mathrm{~h}$ & $24 \mathrm{~h}$ \\
\hline $\mathrm{PO}_{2}$ & I & $17.4 \pm 1.0$ & $40.0 \pm 3.0^{*}$ & $71.8 \pm 3.4^{* \ddagger}$ & $87.9 \pm 6.4^{* \neq}$ & $87.4 \pm 4.9^{*}$ \\
\hline$(m m H g)$ & D & $17.0 \pm 0.8$ & $40.0 \pm 6.4^{*}$ & $54.9 \pm 5.5^{*}$ & $65.9 \pm 6.4^{*}$ & $74.0 \pm 6.9^{*}$ \\
\hline $\mathrm{PCO}_{2}$ & I & $47.9 \pm 0.9$ & $51.9 \pm 2.3$ & $44.9 \pm 1.1$ & $40.2 \pm 1.5$ & $39.6 \pm 1.2$ \\
\hline$(\mathrm{mmHg})$ & D & $48.6 \pm 1.2$ & $52.8 \pm 2.7$ & $46.3 \pm 2.3$ & $45.0 \pm 2.2$ & $44.4 \pm 2.0$ \\
\hline \multirow[t]{2}{*}{$\mathrm{pH}$} & I & $7.33 \pm 0.01$ & $7.23 \pm 0.02 *$ & $7.32 \pm 0.01$ & $7.36 \pm 0.01$ & $7.39 \pm 0.01$ \\
\hline & D & $7.35 \pm 0.01$ & $7.23 \pm 0.03^{*}$ & $7.33 \pm 0.01$ & $7.36 \pm 0.01$ & $7.37 \pm 0.01$ \\
\hline$P_{\mathrm{Na}}$ & I & $145 \pm 1$ & $146 \pm 2$ & $148 \pm 2$ & $149 \pm 1$ & $148 \pm 2$ \\
\hline (mEq/liter) & D & $146 \pm 2$ & $146 \pm 1$ & $147 \pm 1$ & $149 \pm 1$ & $148 \pm 2$ \\
\hline$P_{\mathrm{K}}$ & I & $4.4 \pm 0.2$ & $4.2 \pm 0.1$ & $4.1 \pm 0.1$ & $4.1 \pm 0.1$ & $4.31 \pm 0.1$ \\
\hline (mEq/liter) & D & $4.3 \pm 0.1$ & $4.2 \pm 0.1$ & $4.3 \pm 0.1$ & $4.3 \pm 0.1$ & $4.56 \pm 0.1$ \\
\hline$P_{\mathrm{Osm}}$ & I & $296 \pm 2$ & $295 \pm 3$ & $297 \pm 2$ & $301 \pm 3$ & $300 \pm 3$ \\
\hline$(\mathrm{mOsm} / \mathrm{kg})$ & D & $295 \pm 6$ & $301 \pm 2$ & $295 \pm 3$ & $300 \pm 2$ & $295 \pm 4$ \\
\hline Het & I & $34.1 \pm 1.2^{\ddagger}$ & $32.7 \pm 1.0^{* \pm}$ & $32.1 \pm 1.2^{* \pm}$ & $33.6 \pm 1.3^{\ddagger}$ & $35.0 \pm 1.1^{\ddagger}$ \\
\hline (\%) & D & $37.8 \pm 1.9$ & $37.3 \pm 1.7$ & $36.6 \pm 1.6$ & $38.1 \pm 1.7$ & $38.0 \pm 1.5$ \\
\hline
\end{tabular}

Values are mean \pm SEM measured before (fetus) and 1, 4, 8, and $24 \mathrm{~h}$ after delivery by cesarean section (newborn). P, plasma concentration; $H c t$, hematocrit. ${ }^{*} P<0.05$ compared with fetus. ${ }^{\ddagger} P<0.05$ intact (I) compared with denervated (D) animals.

Fig. 3 illustrates urinary flow rates and $\mathrm{Na}^{+}$excretions measured continuously during the $24 \mathrm{~h}$ after delivery. Urinary flow rates and $\mathrm{Na}^{+}$excretions were greater in denervated than intact lambs in the $4 \mathrm{~h}$ after cesarean delivery.

Urinary osmolality was higher and free water clearance lower in intact than in denervated lambs before and after delivery as shown in Table II. Urinary osmolality increased $(F$ $=4.46 ; P<0.001)$ and free water clearance decreased $(F$ $=3.22 ; P=0.02$ ) in intact lambs $1 \mathrm{~h}$ postnatally; similar changes, though not significant, were also seen in denervated lambs.

Endocrine function. Effects of delivery on plasma aldosterone levels, ANF, and PRA are illustrated in Fig. 4. Plasma aldosterone levels, PRA, and ANF were similar in intact and denervated fetuses $(P>0.05)$. Plasma aldosterone increased 1 $h$ after delivery to similar levels in both groups (Fig. 4), and remained elevated $24 \mathrm{~h}$ after delivery. ANF levels increased after delivery in intact $(F=12.39 ; P<0.0001)$ and denervated lambs $(F=9.94 ; P<0.0001)$, the levels being significantly higher in intact than in denervated newborn lambs $(P<0.05$; Fig. 4) for up to $24 \mathrm{~h}$ after delivery. PRA was higher in intact than in denervated animals at 4 and $24 \mathrm{~h}$ after delivery (Fig. 4).

Fig. 5 shows plasma levels of NE and EPI measured before and after cesarean delivery. Plasma NE and EPI levels tended to be higher in intact than in denervated lambs before and after cesarean delivery. There was a transient increase in plasma catecholamine levels $1 \mathrm{~h}$ after birth in both groups, the increase being similar in intact and denervated lambs.

Renal tissue NE content was $36,044 \pm 6,134 \rho \mathrm{g} / \mathrm{g}$ of cortex in intact kidneys $(n=9)$ and $950 \pm 381 \rho \mathrm{g} / \mathrm{g}$ of cortex in denervated kidneys $(n=9)$. This represented a reduction in NE content of $97.4 \%$ in denervated compared with intact kidneys.

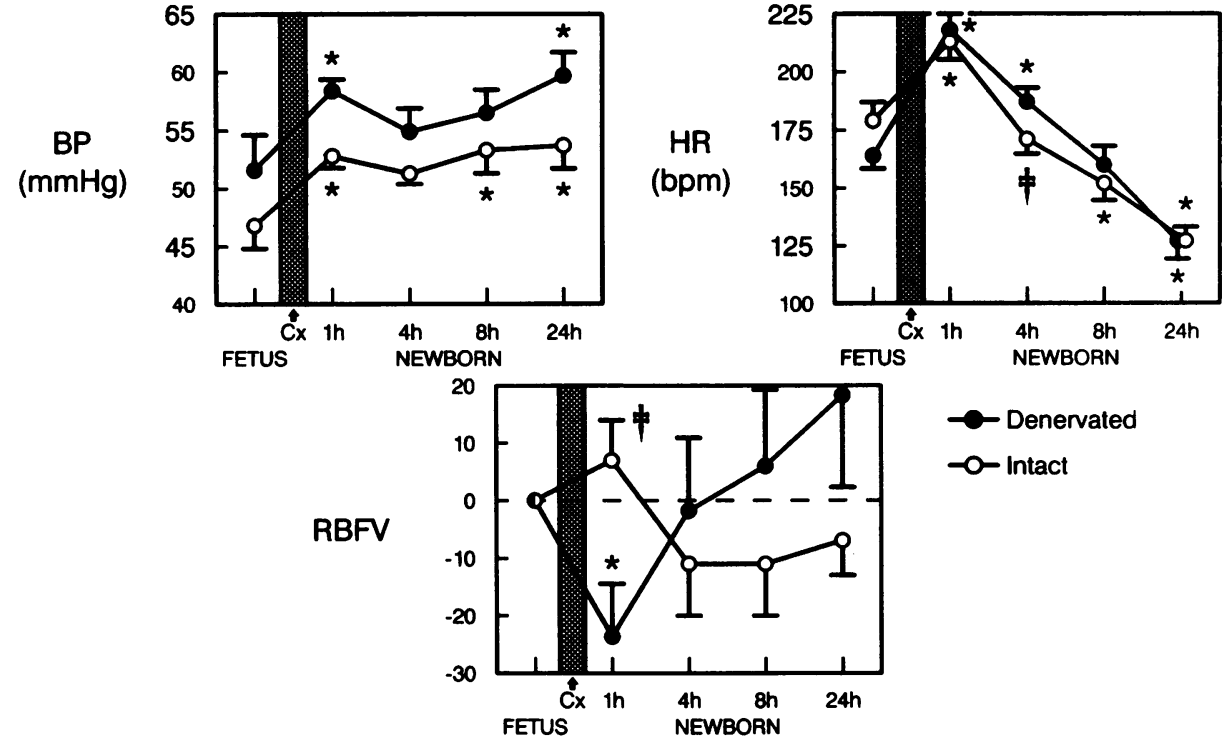

Figure 1. Effects of cesarean delivery on systemic and renal hemodynamics in intact and denervated lambs. $B P$, blood pressure; $H R$, heart rate; $R B F V$, renal blood flow velocity $(\% \Delta)$, before (fetus) and $1,4,8$, and $24 \mathrm{~h}$ after cesarean delivery (newborn). ${ }^{*} P<0.05$ newborn compared with fetus; ${ }^{\ddagger} P<0.05$ intact compared with denervated lambs. 


\begin{tabular}{|c|c|c|c|c|c|c|}
\hline \multirow[b]{2}{*}{ Time } & & \multirow[b]{2}{*}{ Fetus } & \multicolumn{4}{|c|}{ Newborn } \\
\hline & & & $1 \mathrm{~h}$ & $4 \mathrm{~h}$ & $8 \mathrm{~h}$ & $24 \mathrm{~h}$ \\
\hline GFR & I & $4.7 \pm 0.6$ & $5.6 \pm 0.9$ & $4.9 \pm 0.9$ & $6.1 \pm 1.0$ & $6.4 \pm 0.6$ \\
\hline$(\mathrm{ml} / \mathrm{min})$ & D & $5.8 \pm 0.4$ & $7.0 \pm 0.7$ & $6.4 \pm 1.1$ & $6.5 \pm 0.6$ & $6.7 \pm 0.6$ \\
\hline$V$ & I & $0.61 \pm 0.14$ & $0.60 \pm 0.17^{\ddagger}$ & $0.45 \pm 0.14$ & $0.34 \pm 0.05^{*}$ & $0.29 \pm 0.06^{*}$ \\
\hline$(\mathrm{ml} / \mathrm{min})$ & D & $0.7 \pm 0.1$ & $1.1 \pm 0.2^{*}$ & $0.5 \pm 0.1$ & $0.5 \pm 0.1$ & $0.3 \pm 0.04^{*}$ \\
\hline$U_{\mathrm{Na}} V$ & I & $31 \pm 10$ & $64 \pm 20^{* \ddagger}$ & $21 \pm 7^{\ddagger}$ & $14 \pm 4^{*}$ & $14 \pm 5^{*}$ \\
\hline$(\mu E q / \min )$ & D & $45 \pm 6$ & $127 \pm 25^{*}$ & $38 \pm 6$ & $23 \pm 6^{*}$ & $15 \pm 3^{*}$ \\
\hline$U_{\mathbf{K}} V$ & I & $17 \pm 5$ & $18 \pm 5$ & $12 \pm 3$ & $10 \pm 2$ & $9 \pm 1$ \\
\hline$(\mu E q / \min )$ & D & $11 \pm 2$ & $14 \pm 3$ & $10 \pm 1$ & $11 \pm 1$ & $11 \pm 1$ \\
\hline$F E_{\mathrm{Na}}$ & I & $4.5 \pm 1.4$ & $7.8 \pm 1.4^{* \pm}$ & $3.1 \pm 0.8$ & $2.0 \pm 0.5^{*}$ & $1.8 \pm 0.6^{*}$ \\
\hline$(\%)$ & D & $5.6 \pm 0.7$ & $12.3 \pm 2.0^{*}$ & $4.5 \pm 0.8$ & $2.4 \pm 0.6^{*}$ & $1.6 \pm 0.3^{*}$ \\
\hline$F E_{\mathrm{K}}$ & I & $75 \pm 17$ & $69 \pm 19$ & $59 \pm 8^{\ddagger}$ & $42 \pm 4$ & $35 \pm 3^{*}$ \\
\hline (\%) & D & $46 \pm 8$ & $60 \pm 19$ & $41 \pm 7$ & $40 \pm 4$ & $35 \pm 3$ \\
\hline$U_{\text {Osm }}$ & I & $280 \pm 37$ & $373 \pm 23^{* \pm}$ & $266 \pm 41$ & $228 \pm 25$ & $252 \pm 23$ \\
\hline$(m O s m / k g)$ & $\mathrm{D}$ & $252 \pm 39$ & $293 \pm 29$ & $278 \pm 42$ & $198 \pm 21$ & $283 \pm 33$ \\
\hline$C_{\mathrm{H}_{2} \mathrm{O}}$ & I & $0.16 \pm 0.10$ & $-0.08 \pm 0.02^{* \ddagger}$ & $0.14 \pm 0.07$ & $0.12 \pm 0.05$ & $0.06 \pm 0.03$ \\
\hline$(\mathrm{ml} / \mathrm{min})$ & D & $0.22 \pm 0.12$ & $0.19 \pm 0.12$ & $0.13 \pm 0.08$ & $0.22 \pm 0.09$ & $0.04 \pm 0.03$ \\
\hline
\end{tabular}

Values are mean \pm SEM measured before (fetus) and $1,4,8$, and $24 \mathrm{~h}$ after delivery by cesarean section (newborn). GFR, glomerular filtration rate; $V$, urinary flow rate; $U_{\mathbf{x}} V$, excretion rate; $F E_{\mathbf{x}}$, fractional excretion. ${ }^{*} P<0.05$ compared with fetus; ${ }^{\ddagger} P<0.05$ intact (I) compared with denervated (D) animals.

\section{Discussion}

The present study provides the first evidence that the transition from fetal to newborn life is associated with stimulation of renal sympathetic nerves. In the absence of renal nerves, the normal rise in renin release at birth is attenuated, and a greater diuresis and natriuresis occurs in the immediate postnatal period. Renal nerves therefore modulate both renal function and renin release at birth.

In the adult animal, renin release from the kidney occurs through renal vascular baroreceptors, macula densa receptors and renal sympathetic nerves (1). In fetal and newborn animals, renin release can also be promoted by stimulation of renal vascular baroreceptors, and macula densa receptors (2628). Stimulation of neural norepinephrine release by veratridine also results in renin release in vitro from renal cortical slices of fetal and newborn sheep $(4,29)$. In vivo, renin release
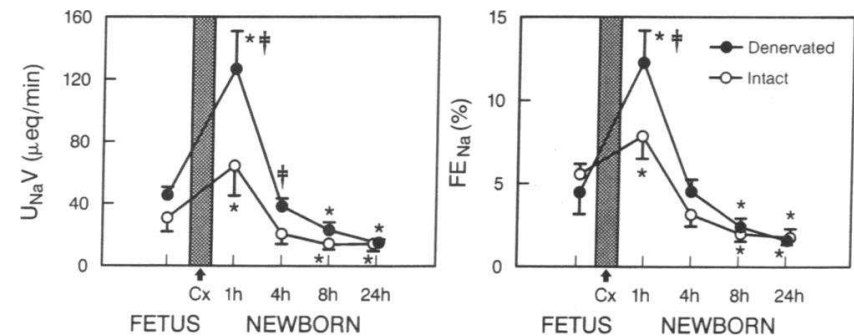

Figure 2. Effects of cesarean delivery on renal function in intact and denervated lambs. Sodium excretion $\left(U_{\mathrm{Na}} V\right)$ and fractional excretion of $\mathrm{Na}^{+}\left(F E_{\mathrm{Na}}\right)$ before (fetus) and 1, 4, 8, and $24 \mathrm{~h}$ after cesarean delivery (newborn). ${ }^{*} P<0.05$ newborn compared with fetus; ${ }^{\ddagger} P<0.05$ intact compared with denervated lambs.
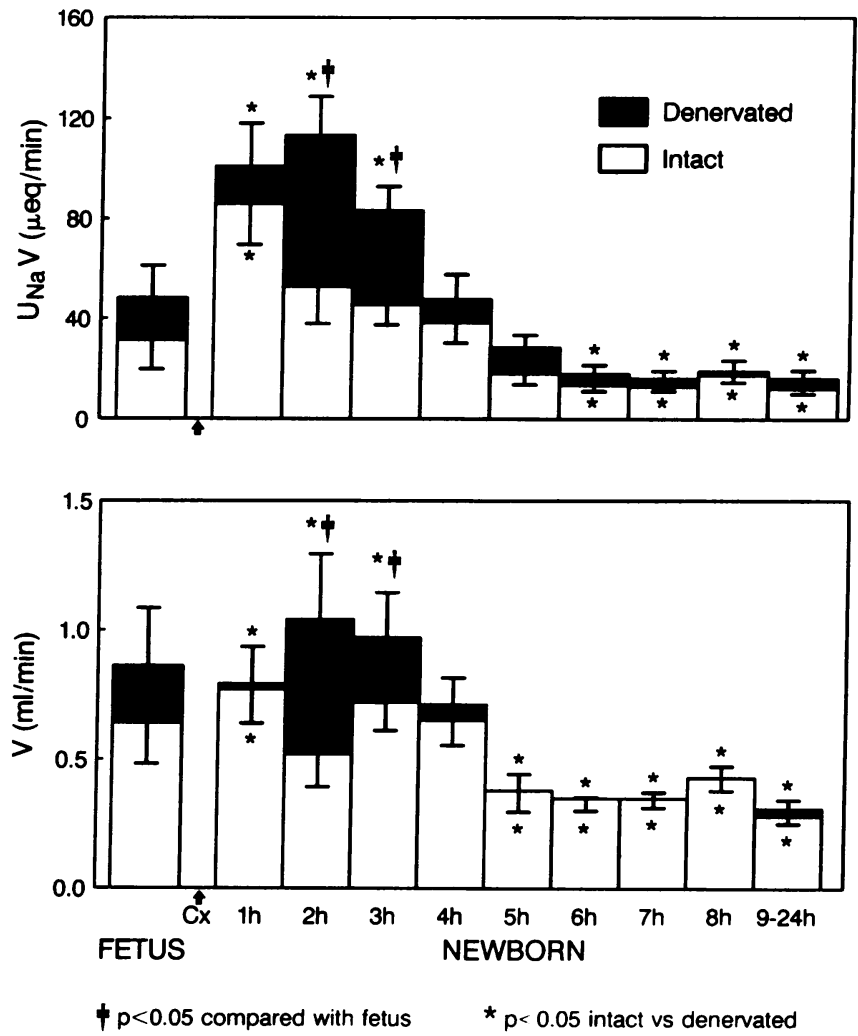

Figure 3. Continuous renal function measurements in the $24 \mathrm{~h}$ after cesarean delivery in intact and denervated lambs. Urinary flow rate $(V)$, and $\mathrm{Na}^{+}$excretion $\left(U_{\mathrm{Na}} V\right)$ measured continuously before (fetus) and for $24 \mathrm{~h}$ after cesarean delivery (newborn). ${ }^{*} P<0.05$ newborn compared with fetus; ${ }^{\ddagger} P<0.05$ intact compared with denervated lambs. 

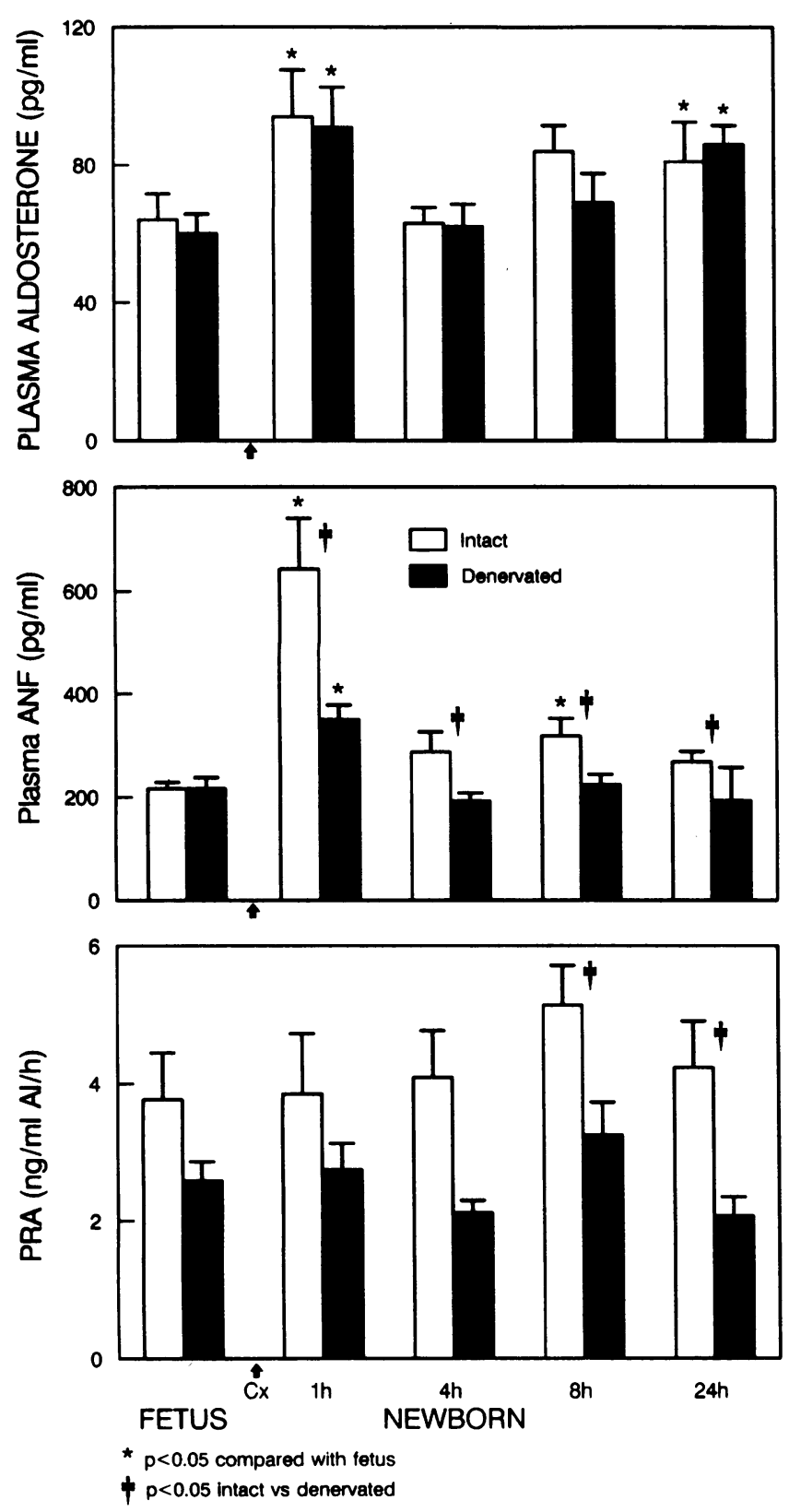

Figure 4. Effects of cesarean delivery on endocrine function. Plasma aldosterone levels, plasma renin activity (PRA), and plasma atrial natriuretic factor (ANF) measured before (fetus) and 1, 4, 8, and 24 $\mathrm{h}$ after cesarean delivery (newborn). ${ }^{*} P<0.05$ newborn compared with fetus; ${ }^{\ddagger} P<0.05$ intact compared with denervated lambs.

can also be stimulated in preweanling Sprague-Dawley rats (30) by activation of $\beta_{1}$-adrenoceptors. In the present study, renal denervation did not alter basal renin release, confirming the previous studies of Smith et al. $(18,31)$ in fetal and newborn sheep. Basal renal sympathetic tone in the fetus and newborn, therefore, does not appear to modulate renin release during resting conditions.

Birth, however, results in significant stimulation of the renin-angiotensin system $(6,7,14)$. Our data demonstrate that the normal rise in PRA at birth is attenuated in the absence of renal nerves. These data confirm that renal sympathetic nerves can modulate renin release during the perinatal period, and demonstrate that an intact renal sympathetic system is necessary for stimulation of the renin-angiotensin system which occurs at birth. This increase in renin and angiotensin II, is thought to be important in influencing some of the circulatory adaptations which occur postnatally, including the rapid decrease in pulmonary vascular resistance $(7,32,33)$. The attenuated rise in PRA in denervated lambs may help to explain the lower arterial oxygen tension seen 4-8 h after cesarean delivery (Table I). Support for this hypothesis is the reduced arterial oxygen tension seen in newborn lambs in which angiotensin II formation or receptor occupancy were blocked by administration of saralasin or captopril, respectively, before birth (7).

In addition to the role of renal nerves in influencing renin release at birth, the present study illustrates that renal denervation alters renal function in the immediate postnatal period. In adult animals, stimulation of renal sympathetic nerves is associated with a significant increase in tubular reabsorption of a number of electrolytes, with predominant effects on $\mathrm{Na}^{+}$and water reabsorption $(1,34)$. In intact and denervated fetuses, $\mathrm{Na}^{+}$excretion and the fractional excretion of $\mathrm{Na}^{+}$were similar, as was urinary flow rate and glomerular filtration, in agreement with our recent studies in near-term fetal sheep (18). During the immediate postnatal period, however, denervated lambs exhibited a greater diuresis and natriuresis than intact lambs. This increased water and $\mathrm{Na}^{+}$excretion in the absence of renal sympathetic nerves occurred despite a transient decrease in renal blood flow velocity in the immediate postnatal period (Fig. 1), resulting probably from a denervation hypersensitivity of the renal vasculature to circulating catecholamines, maximal during this first hour (Fig. 5), and despite similar changes in GFR in the two groups. The slightly, though not significantly higher GFRs seen in denervated lambs (Table I) could account for part of these effects on $\mathrm{Na}^{+}$excretion, through a glomerulotubular imbalance. These small differences in GFR between intact and denervated lambs are, however, not sufficient to account for the greater rise in $\mathrm{Na}^{+}$excretion and fractional $\mathrm{Na}^{+}$excretion in the first $4 \mathrm{~h}$ after birth.

The greater natriuresis in denervated lambs could also not be explained by differences in plasma aldosterone, because the levels were similar in intact and denervated lambs (Fig. 4). Nor could these differences in renal function be attributed to differences in plasma levels of the natriuretic hormone, ANF. On the

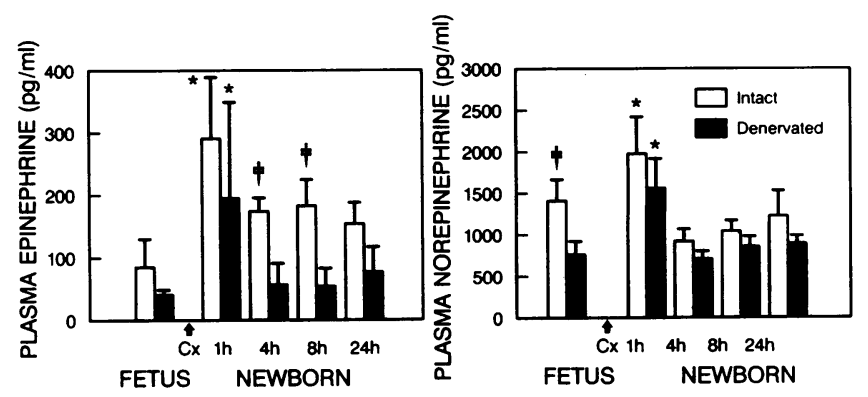

Figure 5. Effects of cesarean delivery on plasma catecholamines. Plasma norepinephrine (NE) and epinephrine (EPI) measured before (fetus) and $1,4,8$, and $24 \mathrm{~h}$ after cesarean delivery (newborn). ${ }^{*} P$ $<0.05$ newborn compared with fetus; ${ }^{\ddagger} P<0.05$ intact compared with denervated lambs. 
contrary, plasma levels of ANF were much lower in denervated than in intact lambs (Fig. 4).

The reason for the greater ANF levels in intact lambs after birth is not clear. In recent studies by our group $(18,31)$, ANF was elevated after volume expansion in fetal sheep and newborn lambs, the levels again being lower in denervated animals. It is plausible to suggest from these observations that there is normally an interaction between the renal sympathetic system and ANF release. Recent studies in adult WKY rats (35) and in humans (36) have purported that ANF activates vagal afferents, thereby inhibiting renal sympathetic activity (35). It is also possible that elevated ANF in intact lambs represents a control factor for fluid and electrolyte homeostasis at birth, which is disturbed in denervated animals in which a greater amount of $\mathrm{Na}^{+}$is lost at birth. Evidence for this is the decrease in hematocrit seen at birth in intact but not in denervated lambs. Further studies are needed to determine the interaction between ANF and the renal sympathetic system in the perinatal period.

The greater natriuresis and diuresis seen in the immediate postnatal period in denervated lambs therefore appears to be attributed to lack of renal sympathetic innervation, and indicates that renal sympathetic nerves play an important role in the adaptation of the kidney to postnatal life. By $24 \mathrm{~h}$ after delivery, however, the effect of renal denervation on water and $\mathrm{Na}^{+}$excretion at birth was absent. Hence, renal sympathetic nerves do not appear to influence basal renal function in newborn lambs beyond the initial transition phase, as previously suggested $(18,31)$. The normal increase in fractional $\mathrm{Na}^{+}$excretion which occurs by $24 \mathrm{~h}$ after cesarean delivery (13-15), was seen in both intact and denervated lambs. Such an effect is not surprising because, in the adult, it is now generally accepted that renal sympathetic nerves are important in influencing $\mathrm{Na}^{+}$ homeostasis during stressful conditions, with a minimal role in influencing basal renal hemodynamics and function (1).

The increased urinary osmolality and decreased free water clearance seen in intact lambs in the immediate postnatal period is in agreement with previous observations $(13,15)$, and probably reflects the increased levels of arginine vasopressin during this time (37). The lack of urinary concentrating capacity after birth in denervated lambs is consistent with the hypothesis of Kurkus et al. (38) who found that denervated kidneys had an elevated tissue water content due probably to disruptions in the medullary gradient. Such a disruption in medullary gradient could prevent the antidiuretic effects of vasopressin. An alternative explanation is that central vasopressin release may be inhibited in renally denervated lambs through loss of renal afferent input, because, at least in the adult, neurosecretion of vasopressin is increased by afferent renal nerve stimulation $(39,40)$. Although there is presently no evidence that afferent renal nerve activity is increased at birth, circulating bradykinin, a substance known to stimulate afferent renal nerves (41), is elevated in the immediate postnatal period $(32,33,42)$. In the present study, however, neither plasma vasopressin nor bradykinin levels were measured.

In conclusion, the present study shows that renal sympathetic nerves play an important physiological role during the transition from fetal to newborn life. In the absence of renal nerves, the normal increase in PRA at birth is attenuated, and there is a greater diuresis and natriuresis in the immediate postnatal period. These data indicate that renal sympathetic nerves regulate fluid and electrolyte homeostasis during the adaptation of the kidney to postnatal demand, and provide the first evidence that birth is associated with stimulation of the sympathetic system.

\section{Acknowledgments}

The authors gratefully acknowledge the assistance of Ruth Hurlburt in the preparation of this manuscript, and Donna Farley and the Immuno Core Laboratory of the University of Iowa in performing the hormonal assays.

This work was supported in part by grants from the National Institute of Health HD-20576, HL-14388, DK-38302, and HL-35600. Edward N. Guillery is supported by National Research Service Award, HL-08366-01.

\section{References}

1. DiBona, G. F. 1982. The functions of the renal nerves. Rev. Physiol. Bio chem. Pharmacol. 94:76-181.

2. Robillard, J. E., K. T. Nakamura, M. K. Wilkin, O. J. McWeeny, and G. F DiBona. 1987. Ontogeny of renal hemodynamic response to renal nerve stimulation in sheep. Am. J. Physiol. 252:F605-F612.

3. Robillard, J. E., F. G. Smith, B. Smith, O. J. McWeeny, and P. A. Jose 1989. Ontogeny of the renal response to alphal-adrenoceptor stimulation in sheep. Pediatr. Res. 25:347A. (Abstr.)

4. Nakamura, K. T., J. M. Klinkefus, F. G. Smith, T. Sato, and J. E. Robillard. 1989. Ontogeny of neuronally released norepinephrine on renin secretion in sheep. Am. J. Physiol. 257:R765-R770.

5. Robillard, J. E., O. J. McWeeny, B. Smith, and G. F. DiBona. 1988. Ontogeny of neurogenic regulation of renal tubular sodium reabsorption in sheep. Pediatr. Res. 23:545A. (Abstr.)

6. Lumbers, E. R., and G. C. Reid. 1977. Effects of vaginal delivery and caesarean section on plasma renin activity and angiotensin II levels in human umbilical cord blood. Biol. Neonate. 31:127-134.

7. Davidson, D. 1987. Circulating vasoactive substances and hemodynamic adjustments at birth in lambs. J. Appl. Physiol. 63:676-684.

8. Padbury, J. F., D. H. Polk, J. P. Newnham, and R. W. Lam. 1985. Neonatal adaptation: greater sympathoadrenal response in preterm than full-term fetal sheep at birth. Am. J. Physiol. 248:E443-E449.

9. Eliot, R. J., A. H. Klein, T. H. Glatz, P. W. Nathanielsz, and D. A. Fisher. 1981. Plasma norepinephrine, epinephrine, and dopamine concentrations in maternal and fetal sheep during spontaneous parturition and in premature sheep during cortisol-induced parturition. Endocrinology. 108:1678-1682.

10. Lagercrantz, H., and P. Bistoletti. 1973. Catecholamine release in the newborn infant at birth. Pediatr. Res. 11:889-893.

11. Eliot, R. J., R. Lam, R. D. Leake, C. J. Hobel, and D. A. Fisher. 1980. Plasma catecholamines concentrations in infants at birth and during the first 48 hours of life. J. Pediatr. 96:311-315.

12. Jones, C. M., and F. C. Greiss, Jr. 1982. The effect of labor on maternal and fetal circulating catecholamines. Am. J. Obstet. Gynecol. 144:149-153.

13. Smith, F. G., and E. R. Lumbers. 1989. Comparison of renal function in term fetal sheep and newborn lambs. Biol. Neonate. 55:309-316.

14. Nakamura, K. T., G. P. Matherne, O. J. McWeeny, B. A. Smith, and J. E. Robillard. 1987. Renal hemodynamics and functional changes during the transition from fetal to newborn life in sheep. Pediatr. Res. 21:229-234.

15. Smith, F. G. 1987. Factors Influencing Fetal and Neonatal Fluid Balance. University of New South Wales, Sydney, Australia. 111-132.

16. Jennings, J. J., and J. P. Crowley. 1972. The influence of mating management on fertility in ewes following progesterone-PMS treatment. Vet. Rec. 90:495-498.

17. Robillard, J. E., and R. E. Weitzman. 1980. Developmental aspects of the fetal renal response to exogenous arginine vasopressin. Am. J. Physiol. 238:F407F414.

18. Smith, F. G., T. Sato, O. J. McWeeny, J. M. Klinkefus, and J. E. Robillard. 1990. Role of renal sympathetic nerves in the response of the ovine fetus to volume expansion. Am. J. Physiol. 259:R 1050-R 1055.

19. Robillard, J. E., K. T. Nakamura, and G. F. DiBona. 1986. Effects of renal denervation on renal responses to hypoxemia in fetal lambs. Am. J. Physiol. 250:F294-F301.

20. Smith, F. G., and E. R. Lumbers. 1988. Changes in renal function following delivery of the lamb by caesarian section. J. Dev. Physiol. 10:145-148.

21. Ito, T., J. Woo, R. Haning, and R. Horton. 1972. A radioimmunoassay for 
aldosterone in human peripheral plasma including a comparison of alternate techniques. J. Clin. Endocrinol. \& Metab. 34:106-112.

22. Robillard, J. E., K. T. Nakamura, V. A. Varille, A. A. Andresen, G. P. Matherne, and D. E. Van Orden. 1988. Ontogeny of the renal response to natriuretic peptide in sheep. Am. J. Physiol. 254:F634-F641.

23. Moyer, T. P., and N. S. Jiang. 1978. Optimized isocratic conditions for analysis of catecholamines by high-performance reversed-phase paired-on chromatography with amperometric detection. J. Chromatogr. 153:365-372.

24. Haber, E., T. Koerner, L. B. Page, B. Kliman, and A. Purnobe. 1969. Application of a radioimmunoassay for angiotensin I to the physiologic measurements of plasma renin activity in normal human subjects. J. Clin. Endocrinol. \& Metab. 29:1349-1355.

25. Zar, J. H. 1984. Biostatistical Analysis. Prentice-Hall, Inc., Englewood Cliffs NJ. 122-235.

26. Smith, F. G., Jr., A. N. Lupu, L. Barajas, R. Bauer, and R. A. Bashore. 1974. The renin angiotensin system in the fetal lamb. Pediatr. Res. 8:611-620.

27. Siegel, S. R., and D. A. Fisher. 1980. Ontogeny of the renin-angiotensinaldosterone system in the fetal and newborn lamb. Pediatr. Res. 14:99-102.

28. Lumbers, E. R., and A. D. Stevens. 1987. The effects of frusemide, saralasin and hypotension on fetal plasma renin activity and on fetal renal function. $J$. Physiol. (Lond.). 393:479-490.

29. Nakamura, K. T., W. V. Page, J. M. Klinkefus, T. Sato, and J. E. Robillard. 1989. Ontogeny of isoproterenol-stimulated renin secretion from sheep renal cortical slices. Am. J. Physiol. 256:R1258-R1263.

30. Kirby, R. F., and A. K. Johnson. 1990. Effects of sympathetic activation on plasma renin activity in the developing rat. J. Pharmacol. Exp. Ther. 253:152 157.

31. Smith, F. G., T. Sato, O. J. McWeeny, L. Torres, and J. E. Robillard. 1989. Role of renal nerves in response to volume expansion in conscious, newborn lambs. Am. J. Physiol. 257:R1519-R1525.
32. Heymann, M. A., A. M. Rudolph, A. S. Nies, and K. L. Melmon. 1969. Bradykinin production associated with oxygenation of fetal lamb. Circ. Res. 25:521-534.

33. Mott, J. C. 1975 . The place of the renin-angiotensin system before and after birth. Br. Med. Bull. 31:44-50.

34. Gottschalk, C. W., N. G. Moss, and R. E. Colindres. 1985. Neural control of renal function in health and disease. In The Kidney: Physiology and Pathophysiology. D. W. Seldin and G. Giebisch, editors. Raven Press, New York. 581-611.

35. Imaizumi, T., A. Takeshita, H. Higashi, and M. Nakamura. 1987. AlphaANP alters reflex control of lumbar and renal sympathetic nerve activity and heart rate. Am. J. Physiol. 253:H1136-H1140.

36. Ebert, T. J., and A. W. Cowley, Jr. 1988. Atrial natriuretic factor attenuates carotid baroreflex-mediated cardioacceleration in humans. Am. J. Physiol. 254:R590-R594.

37. Leffler, C. W., J. Crofton, D. P. Brooks, L. Share, J. R. Hessler, and R. S Green. 1985. Changes in plasma arginine vasopressin during transition from fetus to newborn following minimal trauma delivery of lambs and goats. Biol. Neonate. 48:43-48.

38. Kurkus, J., J. Sadowski, R. Gellert, and S. Krus. 1980. Influence of renal denervation on urine concentration in awake and anesthetized dogs. Eur. J. Clin. Invest. 10:463-467.

39. Day, T. A., and J. Ciriello. 1987. Effects of renal receptor activation on neurosecretory vasopressin cells. Am. J. Physiol. 253:R234-R241.

40. Caverson, M. M., and J. Ciriello. 1987. Effect of stimulation of afferent renal nerves on plasma levels of vasopressin. Am. J. Physiol. 252:R801-R807.

41. Smits, J. F. M., and M. J. Brody. 1984. Activation of afferent renal nerves by intrarenal bradykinin in conscious rats. Am. J. Physiol. 247:R1003-R1008.

42. Melmon, K. L., M. J. Cline, T. Hughes, and A. S. Nies. 1968. Kinins: possible mediators of neonatal circulatory changes in man. J. Clin. Invest. 57:1295-1302. 